\author{
Review Article \\ www.ijrap.net (ISSN:2229-3566)
}

\title{
A CRITICAL REVIEW OF ASRUGDAR
}

Kavita Mule ${ }^{1}$, Nisha Kerle ${ }^{2 *}$

${ }^{1}$ Associate Professor (Guide), Department of Prasuti Tantra and Stree Rog, Yashwant Ayurveda College, Kodoli,

Dist - Kolhapur, Maharashtra, India

${ }^{2}$ PG Student, Department of Prasuti Tantra and Stree Rog, Yashwant Ayurveda College, Kodoli,

Dist - Kolhapur, Maharashtra, India

Received on: 01/02/20 Accepted on: 25/02/20

\author{
*Corresponding author \\ E-mail: nishakerle1928@gmail.com
}

DOI: 10.7897/2277-4343.110246

\begin{abstract}
In present era the disorders of menstruation are the commonest among gynaecological complaints. Asrugdar is one such disorder plagues a large section of the female population during some period of their lifetime. Menorrhagia is characterized by the excessive bleeding per vaginal in amount and duration both. In Ayurvedic classics, Menorrhagia is termed as Asrugdar, means excessive discharge of blood per vaginal. Backache, pain in lower abdomen and weakness are also present in this disease. All the gynaecological disorders come under the heading of Yonivyapad in Ayurvedic classics. Most of the Yonivyapad have characteristic features of menorrhagia such as Raktayoni, Rudhirkashara, Putraghni, Apraja etc. Among Ashta-artavadushti, Raktajaartava-dushti menorrhagia is also found as prominent symptom. According to Ayurveda is basically related to Pitta and Rkata Dusthi with Apanvayu Vaigunya. Hence, the treatment should be based on the use of drugs which are having predominance of Kashaya rasa and Pitta - shamak properties. Kashayarasa is known as best astringent and because of this property Kashaya rasa plays important role in relieving bleeding discharge due its Stambhana action. There is loss of blood, so, the drugs and diet which increases Raktadhatu (Blood) in body are also effective. But prior to Stambhana Chikitsa, Pachana Chikitsa is to be performed as without Amapachana, Stambhana Chikitsa may not show better efficacy Therefore, treatment mainly based on concept of Raktastambhaka as well as Amapachana and Raktavardhaka.
\end{abstract}

Keywords: Asrugdar, Menorrhagia, Yonivyapad, Artavadushti.

\section{INTRODUCTION}

A Healthy Woman lays the foundation of a healthy family and society. In present era with the changing role of woman in society, occupational whereabouts and with increased stress there is increase in gynaecological disorder. In today's scenario, disorder of menstruation is the commonest amongst all the gynaecological complaints which have direct effect on the physical as well as psychological health of the female. Menstruation is the visible manifestation of cyclic physiologic uterine bleeding due to the shedding of the endometrium. It denotes the healthy state of female reproductive system. The menstrual rhythm is invisible interplay of hypothalamus-pituitary-ovarian axis. Any physical and mental disorders disturb the normalcy of menstrual cycle which further leads to impairment in function of reproduction.

Artava or menstrual blood is expelled from the uterus through vagina in biological rhythm of women during her reproductive period i.e. from menarche to menopause. Duration of menstruation varies between 4-5 days and estimated blood loss is around $20-80 \mathrm{ml}$ and average is $50 \mathrm{ml}^{1}$. Once the menstrual starts, it continues cyclically at the interval of 21-35 days with the average of 28 days. A change in the normal volume or duration of menstrual bleeding is one of the commonest cause concerns from health of women. Any abnormality in menstrual cycle leads excessive and prolonged uterine bleeding which is known as Asrugdar in classical textbook. In modern texts excessive bleeding through vagina is mentioned as menorrhagia.

The word Asrugdar has described in Brihatrayee i.e. Charaka Samhita, Sushruta Samhita, Astanga Hridaya and Astanga Sangraha. For excessive bleeding per vaginal, the word Asrugdar has described in Sharangadhara Samhita, Bhava Prakash, Yoga Ratnakara and in commentary on Charaka Samhita by Chakrapani.

Asrugdar (Menorrhagia) is not a disease, but a symptom of so many diseases. Sometimes this symptom becomes so severe and it overshadows the other symptoms of actual disease and patients come to O.P.D. for the treatment of only this symptom. Therefore, Charaka and Vagbhata etc. have described only its symptomatic treatment.

\section{Definition of Asrugdar}

Due to Dirana (excessive secretion) of Asruk (menstrual blood) in this disease, it is known as Asrugdar. Asrugdar is also called Raktapradara due to Pradirana (excessive excretion) of Raja (menstrual blood) ${ }^{2}$.

\section{Aetiology}

According to Acharya Charaka, Sushruta and Vagbhata etc. have described different causes of Asrugdar in their texts which are given below.

\section{Charaka Samhita}

Excessive intake of Lavana, Amla, Katu, Vidahi, Krisara, Payas, Dahi, Mastu, Guru, Snigdha and other Mithya Ahar Sevana. ${ }^{3}$

\section{Sushruta Samhita}

Pittavrita Apana Vayu. ${ }^{4}$ 


\section{Ashtanga Sangraha}

Increase in amount of blood (Ativridhi of Rakta).

\section{Ashtanga Hridaya}

Pittavrita Apana Vayu ${ }^{6}$

\section{Madhava Nidana, Bhava prakash, Yoga ratnakar}

Use of incompatible diet, madya, eating before the previous meal is digested, Indigestion, abortion, excessive coitus, Riding, Walking, Grief emaciation, Weightlifting, Trauma and Daysleeping. $^{7}$

\section{Harita Samhita}

Milk carrying channels of infertile women are filled with Vata thus she has absence of milk secretion besides She also suffers from excessive menstrual bleeding. ${ }^{8}$

\section{Kashyapa Samhita}

Pittavrita Apana Vata and Ativridhi of Rakta9

\section{Bhela Samhita}

If body blood goes to abnormal passage, the woman suffers from pradara $^{10}$

\section{Pathogenesis}

According to Acharya Charaka, aggravated Vata affects uterine vessels and boosts amount of blood and this increase in blood thus causes increase in menstrual blood and creates Rakta-pradara. ${ }^{11}$ Acharya Bhela explains that cause of Raktapradara is vitiated Apatya-marga.

\section{Samprapti Ghataka}

- Dosha - Vata-Pitta- Pradhana,

- Dushya - Rakta (Pradhana) and Artava, Rasa

- Agni - Jathragnimandya

- Adhisthana - Garbhashaya, ArtavavahiStrotasa

- $\quad$ Strotasa - Rakta Vahi, Artavavahi, Rasavahi

- $\quad$ Srtoto-Dusti Prakara - Atipravritti

- Roga Marga - Aabhyantara Asrigdar is the disease of vitiated Rakta and Pittavrita Apana Vayu. Therefore, it can be considered that Vayu can also be vitiated due to being covered by Pitta. The Chala Guna of Vayu and Sara, Drava Guna of Pitta plays an important role in forming basic Samprapti of Asrigdar.

\section{Samanya Lakshana}

The phase of Purvarupa of the Asrugdar is not mentioned in the texts. (Probably there may not be any premonitory symptoms) The Samprapti of Asrugdar is completed by Dosha- Dushya, Sammurchhana and Sthanasamsraya. The vitiated Dosha create various Lakshanas which are Sthanika as well as Sarvadaihika of Asrugdar Charaka says that excessive vaginal bleeding during menstruation is the only symptom of Asrugdar ${ }^{12}$ According to Sushruta Samhita, there are body ache and pain symptoms present in all types of Asrugdar with excessive vaginal bleeding ${ }^{13}$ Dalhana says in his commentary on Sushruta Samhita that burning sensation in lower portion of groin, pelvic region, back, renal region and flanks and severe pain in uterus as symptoms present in Asrugdar ${ }^{14}$. Vriddha Vagbhata has described excessive bleeding during menstrual or intermenstrual period as symptom of Asrugdar. ${ }^{15}$ Bhava Prakash, Madhava Nidana and Yoga Ratnakar have described the same as in Sushruta Samhita i.e. body ache and pain in Asrugdar.

\section{Classification of Rakta-pradara}

Acharya Charaka has described four types of Asrugdar i.e. Vataja, Pittaja, Kaphaja and Sannipataja Asrugdar ${ }^{16}$. Acharya Sushruta has mentioned 'all types of Asrugdar' along with general clinical features of Asrugdar but has not described any classification. ${ }^{17}$ Most of Acharyas have mentioned four types of Asrugdar in their texts.

\section{Treatment}

Treatment of Asrugdar has described under following headings:

- Principles of treatment

- General treatment

- Specific treatment according to Doshas.

\section{Principles of Treatment/Line of Treatment}

- Just like raktayoni, here also haemostatic drugs should be used giving due consideration to the association of dosa diagnosed on the basis of colour and smell of the blood ${ }^{18-20}$.

- Pachana Chikista - Tikta Rasa in Rakta Samgrahana and Dosha Pachana while treating Raktapradara ${ }^{21}$.

- Treatment prescribed for Vatala etc. Gynaecological disorder should also be used in respective asrugdar ${ }^{22}$

- Treatment prescribed for raktatisara (diarrhoea with blood), raktapitta (bleeding diathesis), raktarsha (bleeding piles), guhyaroga (diseases of reproductive system) and abortions is also useful $1^{23-25}$

- A young woman, using congenital diet, having less complications should be treated on the line of adhogaraktapitta. $^{26}$

- Use of basti is beneficial. ${ }^{27,28}$

- Purgation cures menstrual disorder. ${ }^{29}$

\section{General treatment}

General treatment consists of external/local and internal/systemic both i.e. some remedies are effective by their local application to cure Asrugdar and some are beneficial to treat the disease by their internal i.e. oral use. Both of these i.e. external and internal medicines are broadly described in detail under different headings and given below:

\section{Drugs for external use}

- Shodhana - In all types of Pradara is the beginning "Emesis "should be induced. ${ }^{30}$

- Northwards situated root of "Vyaghranakhi" grown in sacred place, uprooted during uttaraphalguninaksatra and tied in the waist cures raktapradara. ${ }^{31}$

- Use of satapuspa oil in the form of inhalation and massage is beneficial $^{32}$

- Uses of two or three Asthapanabastis followed by Uttarbasti is beneficial ${ }^{33-35}$. This should be given during the period of Artava (the period following menstrual bleeding), because during this period the uterus or vagina is free from covering or their orifices are open, thus receive the function easily, however during emergency this basti can be used at any time. 
- In asrugdar following basti are beneficial.

- Chandanadiniruha basti, Rasnadiniruha basti, Kushadiniruha basti, Rodhradi Asthapana basti, Madhukadi Anuvasana basti, Mustadi Yapana basti.

- Application of Padmaka, Seeds of Utpala and trapusa, Satavari, Vidarikanda and ikshu root pounded together mixed with Shatadhouta ghrita into Vagina, over the head and all over body alleviates Pradara. ${ }^{36}$

- Yonipichu - Oil cooked with Mudgaparni is used to impregnate a rolled piece of cotton for keeping into vagina. ${ }^{37}$

\section{Drugs for Internal/oral use}

\section{- Rasaushadhi Kalpana}

Pradararipu Rasa $^{38}$ Bolaparpati, ${ }^{39}$ PradarantakaRasa ${ }^{40}$, Balasooryodaya $\mathrm{Rasa}^{41}$, Chandrakala $\mathrm{Ras}^{42}$, Maha Chandrabala Rasa $^{43}$, Bolbaddha Rasa.

\section{- Vati Kalpana (Tablets)}

Gokshuradi Guggul $^{44}$, Chandraprabha Vati ${ }^{45}$

\section{- Kwath Kalpana (Decoctions)}

Darvyadi decoction ${ }^{46}$, Nyagrodhadi Kashaya ${ }^{47}$, Eladi kwath ${ }^{48}$ Aatrushakadikwath.

\section{- Arishta and Asava Kalpana}

Lodhrasava, Patrangasava, Ashokarishta.

\section{- Awaleha Kalpana}

Khandakushmandawaleha ${ }^{49}$, Brihatkushmandawaleha, Khandakushmandaka, Khandaamalaka. ${ }^{50}$ Jeerakawaleha, Kutajadi Raskriya.

\section{- Kshirapaka Kalpana}

Milk boiled with decoction of ashoka bark and cooled should be taken. ${ }^{51}$

\section{- Ghrita and Tail Kalpana}

Sheetakalyanaka Ghrita, ${ }^{52}$ Shalmali Ghrita ${ }^{53}$, Mudgadya Ghrita, Shatavari Ghrita, Kashmari Ghrita, Ashoka Ghrita, Patadi Ghrita, Jambvadi Ghrita, Shatavari Taila and Shatapushpa Tail.

\section{- Kalka and Churna Kalama}

Pestle root of Tanduliyaka with honey, ${ }^{54}$ Rasanjana and honey (mixture) should be taken with rice-water, Pushyanuga Churna, Powder of Indrayava and sugar taken with overnight kept water, Powdered root of Bala should be used with Milk, Powdered Bharangi and Nagara are used with rice water. Bhumyamalakichurna.

\section{- Kashaya}

Musalyadi Kashaya, Baladi Kashaya. ${ }^{55}$

- Use of Ekala Aushadhi (Single drug preparation)

Ashoka, Kamal, Durva Swarasa, Kutaja, Nagkesar etc. ${ }^{56}$

\section{- Shodhana with Virechana karma}

Ayurvedic management is a good alternative to Hormonal therapy as it has no side effects with minimal recurrence rate. Once, Shodhana is done there is less chance of recurrence of the disease. As, vitiation of Pitta dosha is there in Raktapradra so, Virechana karma was advocated according to the general condition of the patient. Moreover, Kashyapa has quoted that purgation cures menstrual bleeding.

\section{Pathya-apathya}

Wholesome diet recommended in Asrugdar

Godhuma, Shasthikashal, Jangalmamsa Rasa, Pakwa Kushmanda, Pattura, Patola, Tandaleeyaka, Draksha, Dadima, Kharjoora, Dhatriphala, Ghrita, Madhu.

Unwholesome diet in Asrugdar

Katu-Amla-Lavanaahara, Ksharadravya, Matsya, Madya, Vidhahiahara, Masha, Nispava, Tila, Kulattha, Lashuna, Dadhi.

\section{DISCUSSION}

In Ayurvedic classics, all gynaecological disorders come under a big heading 'Yonivyapada'. Menorrhagia is found as symptoms in so many Yonivyapada such as Rakta yoni by Acharya Vagbhata. And Asrijayonivyapada described by Acharya Charaka, also have the Menorrhagia as main symptom. Acharya Sushruta has described the Yonivyapada 'Lohitakshara' which also consists of menorrhagia as a symptom. Complications of Asrugdar includes weakness, giddiness, mental confusion, feeling of darkness, dyspnoea, thirst, burning sensation, delirium, anaemia, drowsiness, convulsion and other disorders due Vata vitiation because of excessive bleeding per vaginal. Prophylaxis of Asrugdar is possible only due the avoidance of all etiological factors causing Raktapradara Asrugdar Chikitsa resembles and adopts core concepts of Rakta Pittahara Chikitsa. It is said that in all kinds of Pradara, the management principles of Raktatisara, Raktapitta and Raktarshas are to be adopted. The reason behind this indication is again the concept of, Pittanubandhatva, Rakta Dushyatva, Nidana Samyatvam are the factors found commonly in both the above Stambhana is the basic treatment principle in Srava Pradhana disorders particularly in Asrugdar. Dosha Pachana has specific role in its management. Further Acharya Charaka explains the role of Tikta Rasa in Rakta Samgrahana and Dosha Pachana while treating Raktapitta. Here the Tikta Rasa and Kashaya rasa is used as a Pachaka particularly Dosha Pachaka of Pitta and agnideepana. Stambhana works very effectively when Doshas are in Niramastate. Hence, Pachana followed by Stambhana certainly provides a great cure in Raktapradara disease. Shodhana is done there is less chance of recurrence of the disease. As, vitiation of Pitta dosha is there in Raktapradra so, Virechna karma was advocated according to the general condition of the patient. Moreover, Kashyapa has quoted that purgation cures menstrual bleeding. Bhavaprakash, Yoga Ratnakar, Charaka Samhita, Sushruta Samhita and other Ayurvedic classics have described formulations of Prameharogadhikar are very effective in Pradararoga. This is only based on the fact that both types of diseases have been characterized by Atipravriti type of Srotodusti.

\section{CONCLUSION}

Menorrhagia is a common complaint present in women. According to signs and symptoms Asrugdar correlated with Menorrhagia. Nidanparivarjana plays important role in asrugdarchikitsa. From different Granthas, we can conclude that chikitsa of asrugdar should be Deepana, Pachana, Rasayana, 
Vata-Pittashamaka and Raktastambhana. The treatment of asrugdar includes use of drugs and formulation which have property of Kashaya and Tikta Rasa. Raktavardhaka drugs help in improving health of women.

\section{REFERENCES}

1. Hiralal Konar, D.C. Dutta, Textbook Of Gynaecology, 7th Edition, New Central Book Agency, Calcutta, Publications; 2013.

2. Acharya Charaka, Charaka Samhita (Chikitsa sthanaadhyay 30 yonivyapadchikitsa), Hindi Translation by Pandit Kashinath Nath Shastri and Dr Gorakh Nath Chaturvedi, Reprint, Varanasi, Chaukhambha Sanskrit Series; 1997. p. 777. Edition $7^{\text {th }}$

3. Acharya Charaka, Charaka Samhita (Chikitsa sthanaadhyay 30 yonivyapadchikitsa), Hindi Translation by Pandit Kashinath Nath Shastri and Dr Gorakh Nath Chaturvedi, Reprint, Varanasi, Chaukhambha Sanskrit Series; 1997. p. 777. Edition $7^{\text {th }}$

4. Acharya Sushruta, Sushruta Samhita (Nidanasthana 1 vatvyadhinidan), Ayurveda Tatva Sandipika, Hindi commentary by Ambika Dutta Shastri, Chaukhambha Sanskrit Series; 2003. p. 231. Edition $1^{\text {st }}$

5. Acharya Vriddha Vagbhat, Ashtanga Samgrah (Sutra sthana19, Doshadivigyaniya), Jeevan Hindi Commentary by Dr Shailaja Srivastawa, Chaukhambha Orientalia; 2006. p. 328.

6. Acharya Vriddha Vagbhat, Astanga Hrudya (Nidanasthana 16, Vatashonit), Indu Sanskrit Commentary by Vaidya Anant Damodar Athawale, Pune; 1980. p. 401. Reprint 2010

7. Madhav Nidan $61 / 1$ and bhav. Pra chi. $68 / 1-2$, Yogratnakar. Streerog chi adhaya, Hindi Tika, Vol. I, By Ayurvedacharya Shri Yadunandanopadhyay, Chaukahmbha Sanskrit Sansthan, Varanasi, Reprint Edi; 2005.

8. Harita Samhita, Pratham sthana, adhyaya 8, Kshirvarga 10, text with 'nirmala' Hindi commentary edited by Vaidya Jaymini Pandey, Choukhmba Visvabharati, Varanasi, edition $1^{\text {st; }} ; 2005$.

9. Acharya Vridha Jeevak, Kashyap Samhita, Vidyotini Hindi Commentary by Sri Saya Pal Bhishagcharya, Chaukhambha Sanskrit Sansthan, Varanasi, Sutra sthana 27/62-63 (Rogaadhyaya); 1998. p. 46. Edition 9th

10. Acharya Bhel, Bhel Samhita Sharirsthana (6, Sharirvichiyaadhaya), Vidyotini Hindi Commentary by Dr. Swaminatha Mishra, Choukhamba Surbharati Prakashna. p. 111. Edition $1^{\text {st }}$.

11. Acharya Charaka, Charaka Samhita (Chikitsa sthanaadhyay 30 yonivyapadchikitsa), Hindi Translation by Pandit Kashinath Nath Shastri and Dr Gorakh Nath Chaturvedi, Reprint, Varanasi, Chaukhambha Sanskrit Series; 1997. p. 777. Edition $7^{\text {th }}$.

12. Acharya Charaka, Charaka Samhita (Chikitsa sthanaadhyay 30 yonivyapadchikitsa), Hindi Translation by Pandit Kashinath Nath Shastri and Dr Gorakh Nath Chaturvedi, Reprint, Varanasi, Chaukhambha Sanskrit Series; 1997. p. 777. Edition $7^{\text {th }}$

13. Acharya Sushruta, Sushruta Samhita (Sharira Shana 2, Shukrashonita), Ayurveda Tatva Sandipika, Hindi commentary by Ambika Dutta Shastri, Chaukhambha Sanskrit Series; 2003. p. 12. Edition $1^{\text {st }}$

14. Acharya Sushruta, Sushruta Samhita (Uttara Tantra 38, Yonivyapadpraticheda), Ayurveda Tatva Sandipika, Hindi commentary by Ambika Dutta Shastri, Chaukhambha Sanskrit Series; 1998. p. 205. Edition $1^{\text {st }}$

15. Acharya Vriddha Vagbhat, Ashtanga Samgrah (Sharira Shana 1, Putrakamiya), Indu Sanskrit Commentary by Vaidya Anant Damodar Athawale, Pune; 1980. p. 262.
16. Acharya Charaka, Charaka Samhita (Chikitsa sthanaadhyay 30 yonivyapadchikitsa), Hindi Translation by Pandit Kashinath Nath Shastri and Dr Gorakh Nath Chaturvedi, Reprint, Varanasi, Chaukhambha Sanskrit Series; 1997. p. 778. Edition $7^{\text {th }}$

17. Acharya Sushruta, Sushruta Samhita (Uttara Tantra 38, Yonivyapadpraticheda), Ayurveda Tatva Sandipika, Hindi commentary by Ambika Dutta Shastri, Chaukhambha Sanskrit Series; 1998. p. 310. Edition 1st

18. Acharya Charaka, Charaka Samhita (Chikitsa sthanaadhyay 30 yonivyapadchikitsa), Hindi Translation by Pandit Kashinath Nath Shastri and Dr Gorakh Nath Chaturvedi, Reprint, Varanasi, Chaukhambha Sanskrit Series; 1997. p. 763. Edition $7^{\text {th }}$

19. Acharya Vriddha Vagbhat, Ashtanga Samgrah (Uttara Tantra 39, Gruhyarognpraticheda), Indu Sanskrit Commentary by Vaidya Anant Damodar Athawale, Pune; 1980. p. 837.

20. Acharya Vagbhat, Ashtanga Hridaya (Uttara Tantra 34, Gruhyarogpraticheda) Vidyatini Hindi commentary by Atri Dev Gupta, Chaukhambha Sanskrit Sanshan, Varanasi; 1993. p. 573. Reprint 2010 .

21. Yadavji Trikakamji Charaka Samhita of Agnivesha. Varanasi; Chaukhamba Surabharti Prakashana; Reprint 2013. Chikitsa Sthana (4/29, Raktapittachikitsa); p. 430.

22. Acharya Charaka, Charaka Samhita (Chikitsa sthanaadhyay 30 yonivyapadchikitsa), Hindi Translation by Pandit Kashinath Nath Shastri and Dr Gorakh Nath Chaturvedi, Reprint, Varanasi, Chaukhambha Sanskrit Series; 1997. p. 780. Edition $7^{\text {th }}$

23. Acharya Charaka, Charaka Samhita (Chikitsa sthanaadhyay 30 yonivyapadchikitsa), Hindi Translation by Pandit Kashinath Nath Shastri and Dr Gorakh Nath Chaturvedi, Reprint, Varanasi, Chaukhambha Sanskrit Series; 1997. p. 780. Edition 7th

24. Acharya Sushruta, Sushruta Samhita (Sharira Sthana 2, Shkurashonita), Ayurveda Tatva Sandipika, Hindi commentary by Ambika Dutta Shastri, Chaukhambha Sanskrit Series; 2003. p. 12. Edition 1st

25. Acharya Vriddha Vagbhat, Ashtanga Samgrah (Sharira Shana1, Putrakamiya), Indu Sanskrit Commentary by Vaidya Anant Damodar Athawale, Pune; 1980. p. 262.

26. Acharya Sushruta, Sushruta Samhita (Sharira Sthana 2, Shkurashonita), Ayurveda Tatva Sandipika, Hindi commentary by Ambika Dutta Shastri, Chaukhambha Sanskrit Series; 2003. p.12. Edition 1st

27. Acharya Vriddha Vagbhat, Astanga Samgrah (Chikitsa Sthana 24, Vatashonitachikitsa), Indu Sanskrit Commentary by Vaidya Anant Damodar Athawale, Pune; 1980. p. 428.

28. Acharya Sharngadhara, Sharngadhara Samhita (Uttarkhanda 5, Bastividhi), Dipika Hindi Commentary by Brahmanand Tripathi, Reprint, Varanasi, Chaukhambha Sanskrit Pratisthana; 1998. p. 361. Edition 1st

29. Acharya Vridha Jeevak, Kashyap Samhita (Siddhisthana 2, Trilakshana siddhi), Vidyotini Hindi Commentary by Sri Saya Pal Bhishagcharya, Chaukhambha Sanskrit Sansthan, Varanasi; 1998. p. 150. Edition 9th

30. Vangasena Samhita (Chikistasara Samgrahana vol.2), by Dr. Nirmal Saxena, Chaukhamba Sanskrit Prakashana, chapter 73 (Pradaraadhikar). Edition; 2014. p. 961.

31. Bhavprakasha Madhyam Khanda, Vidyotini Hindi Commentary by Jayakrushnadas Haridas Gupta, Chaukhamba Prakashana, Varanasi, Chikitsa sthana (67/12, Pradaradhikar); 1998. p.795. Edition 1st

32. Acharya Vridha Jeevak, Kashyap Samhita (Kalpasthana, Shatpusphaadhaya), Vidyotini Hindi Commentary by Sri Saya Pal Bhishagcharya, Chaukhambha Sanskrit Sansthan, Varanasi; 1998. p. 187. Edition 9th 
33. Acharya Charaka, Charaka Samhita (Chikitsa sthanaadhyay 30 yonivyapadchikitsa), Hindi Translation by Pandit Kashinath Nath Shastri and Dr Gorakh Nath Chaturvedi, Reprint, Varanasi, Chaukhambha Sanskrit Series; 1997. p. 985. Edition 7th

34. Acharya Vriddha Vagbhata, Ashtanga Samgrah (Sutra Sathan 28, Bastividhi), Indu Sanskrit Commentary by Vaidya Anant Damodar Athawale, Pune; 1980. p. 215.

35. Acharya Vagbhata, Ashtanga Hridaya (Sutra Sthana 19, Basti vidhi) Vidyatini Hindi commentary by Atri Dev Gupta, Chaukhambha Sanskrit Sanshan, Varanasi; 1993. p. 125-126.

36. Vangasena Samhita (Chikistasara Samgrahana vol.2) by Dr. Nirmal Saxena, Chaukhamba Sanskrit Prakashana, chapter 73 (pradaraadhikara). Edition; 2014. p. 961.

37. Vangasena Samhita (Chikistasara Samgrahana vol.2) by Dr. Nirmal Saxena, Chaukhamba Sanskrit Prakashana, chapter 73 (pradaraadhikar). Edition; 2014. p. 961.

38. Yoga Ratnakar, Hindi Commentary by Achrya Laxmipati Shastri (Pradara Rogachikitsa), Published by Chaukhambha Prakashan, Varanasi. Reprint; 2013. p. 401.

39. Yoga Ratnakar (Pradara Rogachikitsa), Hindi Commentary by Achrya Laxmipati Shastri, Published by Chaukhambha Prakashan, Varanasi. Reprint; 2013. p. 401.

40. Basavraj, Basavarajeeyam (Chapter 16, Asrugdarnidanalakshanachikstadiadhaya) by Prof. M. S. Krishnamurti, Chaukhamba Orientalia, Varanasi, $1^{\text {st }}$ edition reprint; 2005. p. 402.

41. Basavraj Basavarajeeyam (Chapter 16 , Asrugdarnidanalakshanachikstadiadhaya) by Prof. M. S. Krishnamurti, Chaukhamba Orientalia, Varanasi, $1^{\text {st }}$ edition reprint; 2005. p. 402

42. Basavraj Basavarajeeyam (Chapter 16, Asrugdarnidanalakshanachikstadiadhaya) by Prof. M. S. Krishnamurti, Chaukhamba Orientalia, Varanasi. $1^{\text {st }}$ edition reprint; 2005. p. 402.

43. Basavraj Basavarajeeyam (Chapter 16, Asrugdarnidanalakshanachikstadiadhaya) by Prof. M. S. Krishnamurti, Chaukhamba Orientalia, Varanasi. $1^{\text {st }}$ edition reprint; 2005. p. 403.

44. Acharya Sharngadhara, Sharngadhara Samhita (Madhyam khanda, Vatikalpana), Dipika Hindi Commentary by Brahmanand Tripathi, Reprint, Varanasi, Chaukhambha Sanskrit Pratisthana; 1998. p. 206. Edition 1st

45. Yoga Ratnakar (Pradara Rogachikitsa), Hindi Commentary by Acharya Laxmipati Shastri, Published by Chaukhambha Prakashan, Varanasi. Reprint; 2013. p. 87.
46. Acharya Bhav Mishra, Bhav Prakash Nighantu (Uttarkhanda), Hindi Commentary by Shree Brahma Shankar Mishra, Chaukhambha Sanskrit Bhawan, Varanasi; 2009. p. 762.

47. Acharya Sharngadhara, Sharngadhara Samhita (Madhyam khanda Vatikalpana), Dipika Hindi Commentary by Brahmanand Tripathi, Reprint, Varanasi, Chaukhambha Sanskrit Pratisthana; 1998. p. 149-150. Edition 1st

48. Harit Samhita (Tritiyasthana 13, Raktapittaaadyaya - By Vd. Jaymini Pandey. Chaukhamba Prakashan, Varanasi. $1^{\text {st }}$ Edition; 2010. p. 308.

49. Acharya Bhav Mishra, Bhav Prakash Nighantu (Uttarkhanda), Hindi Commentary by Shree Brahma Shankar Mishra, Chaukhambha Sanskrit Bhawan, Varanasi; 2009. p. 118. Edition 4th

50. Acharya Bhav Mishra, Bhav Prakash Nighantu (Uttarkhanda), Hindi Commentary by Shree Brahma Shankar Mishra, $4^{\text {th }}$ edition, Varanasi, Chaukhamba Vishwabharati; 1988. p. 118-119.

51. Acharya Bhav Mishra, Bhav Prakash Nighantu (Uttarkhanda), Hindi Commentary by Shree Brahma Shankar Mishra, Chaukhambha Sanskrit Bhawan, Varanasi; 2009. p. 762. Edition 4th

52. Yoga Ratnakar (Pradara Roga Chikitsa), Hindi Commentary by Acharya Laxmipati Shastri, Published by Chaukhambha Prakashan, Varanasi. Reprint; 2013. p. 400.

53. Yoga Ratnakar (Pradara Roga Chikitsa), Hindi Commentary by Acharya Laxmipati Shastri, Published by Chaukhambha Prakashan, Varanasi. Reprint; 2013. p. 400.

54. Acharya Sharngadhara, Sharngadhara Samhita (Madhyam khanda), Dipika Hindi Commentary by Brahmanand Tripathi, Reprint, Varanasi, Chaukhambha Sanskrit Pratisthana; 1998. p. 237. Edition 1st

55. Yoga Ratnakar (Pradara Roga Chikitsa), Hindi Commentary by Acharya Laxmipati Shastri, Published by Chaukhambha Prakashan, Varanasi. Reprint; 2013. p. 398.

56. Priya Nighantu by Priyavat Sharma, Chaukhamba Surbharati Prakashna, chapter 1, Haritakiyadivarga 1/99; 2004. p. 23. Edition $2^{\text {nd }}$

\section{Cite this article as:}

Kavita Mule and Nisha Kerle. A Critical Review of Asrugdar. Int. J. Res. Ayurveda Pharm. 2020;11(2):133-137 http://dx.doi.org/ $10.7897 / 2277-4343.110246$

Disclaimer: IJRAP is solely owned by Moksha Publishing House - A non-profit publishing house, dedicated to publishing quality research, while every effort has been taken to verify the accuracy of the content published in our Journal. IJRAP cannot accept any responsibility or liability for the site content and articles published. The views expressed in articles by our contributing authors are not necessarily those of IJRAP editor or editorial board members. 